\title{
Thermal inactivation studies on toxic seeds from fruits of the Brazilian Central Plain
}

\author{
Karla de Aleluia BATISTA ${ }^{1}$, Luann Guilherme Vieira dos REIS ${ }^{2}$, Luane Ferreira GARCIA², \\ Kátia Flavia FERNANDES², Armando Garcia RODRIGUEZ ${ }^{2 *}$
}

\begin{abstract}
Seeds from endemic Brazilian fruits (Mangaba, Cagaita, Jatobá and Araticum), previously confirmed to be toxic using Artemia salina bioassay were exposed to different temperatures and heating times aiming to test inhibitory effects on toxicity, as a first approach to characterize and identify toxic compounds and their thermal stability. After treatment, water extracts from kernels were filtered and added to Artemia cultures for 24 hours after which the survival of cultures was calculated. The inhibitory effect of temperature on toxicity was significant, whereas toxins from Mangaba and Cagaita were the most labile, showing $90 \%$ Artemia survival after heating at $78^{\circ} \mathrm{C}$ for 2 minutes and 10 minutes, respectively. The most resistant toxins were those found in Araticum seeds which remained active ( $0 \%$ Artemia survival), even after heating at $160{ }^{\circ} \mathrm{C}$ for $12 \mathrm{~min}$. Response surfaces and statistical multivariate analysis showed a significant effect for both temperature and heating time (linear fit) on Cagaita and Mangaba toxicity reduction, while the temperature factor was more significant in Jatobá samples. The results confirm the need to adopt safety procedures during the manufacture of industrialized derivatives for these fruits, in order to minimize toxicity risks after their consumption.
\end{abstract}

Keywords: kernels; heating; food toxicology; bioassay.

Practical Application: Use of simple procedures to inactivate toxins, increasing food safety and reducing the risk of poisoning by consumption of fruit products.

\section{Introduction}

The Brazilian Central Plain (known as the Cerrado) is highly rich in a variety of edible and tasty endemic fruits that grow naturally in that extensive biome. Most of these fruits are consumed fresh but in recent years various manufactured products such as ice cream, jellies, desserts and fermented drinks began to appear in markets, being widely appreciated by local buyers and tourists, thereby increasing commercial options for small countryside enterprises and potential for the expansion of production and export to other countries. Much research has been conducted into the study of nutritional value, and the physical and chemical properties of such fruits and derivatives (Rocha et al., 2008; Silva et al., 2004, 2009), nevertheless other important points such as natural toxic compounds are not commonly studied.

Several studies have pointed to the presence of antinutritional factors and toxic compounds like hydrocyanic acid and acetogenins, among many others, in seeds from commercial fruits (Midio \& Martins, 2000; Araújo, 2004; Caramori et al., 2004; Silva, 2011). Toxicity risk is insignificant when fresh fruits are consumed but it becomes significant in manufactured and industrial products, where seeds may be partially broken during pulp removal. Indeed, significant cyanide concentrations in peach and cherry liqueurs, juices and wines have been reported (Fernandez \& Novelli, 1997). Unfortunately, there is no clinical data available about toxicity from fruit seeds or industrial derivatives in Brazil.
Previous studies using Artemia salina bioassay showed the presence of toxic compounds in the seeds of Cagaita (Eugenia dysenterica), Mangaba (Hancornia speciosa), Jatobá (Hymenaea stigonocarpa) and Araticum (Annona crassiflora). Although dose - response curves have suggested that hydrocyanic acid is responsible for the toxicity found in some of these seeds, cyanide-specific Guignard tests showed negative results in all tested samples (Fonseca et al., 2013).

The scope of the present study was to assess the effect of different temperatures and heating times on the toxicity of seeds obtained from the Brazilian fruits listed above, trying to establish a relationship between the observed effect and possible toxic compounds. Any observed inactivation effect could be useful as a preventive treatment before the manufacture of fruit derivatives.

\section{Materials and methods}

\subsection{Experimental design}

The effect of temperature and heating time on the toxicity of seeds was evaluated using a Central Composite Rotatable Design (CCRD). The two independent variables for the experimental design which used Cagaita and Mangaba seeds were confined to two levels: $78{ }^{\circ} \mathrm{C}$ (low level) and $110^{\circ} \mathrm{C}$ (high level) for temperature and to $0.5 \mathrm{~min}$ (low level) and $10 \mathrm{~min}$ (high level) for time. A central point $\left(98^{\circ} \mathrm{C} ; 2 \mathrm{~min}\right)$ with two replicates was 
also included for statistical evaluation (at a confidence level of 95\%). For Jatobá and Araticum seeds temperature levels were defined between $105{ }^{\circ} \mathrm{C}$ (low level) and $160{ }^{\circ} \mathrm{C}$ (high level) and time between 6 and $12 \mathrm{~min}$, while a central point was set at $130{ }^{\circ} \mathrm{C} ; 9 \mathrm{~min}$. Lower and higher levels for each seed were determined after previous screening experiments were conducted which aimed to find temperature and time conditions for $0 \%$ and $100 \%$ Artemia survival, measured after bioassay toxicity tests.

\subsection{Seed samples}

Fresh mature Cagaita and Mangaba fruits were collected in the Agronomy School orchard of the Federal University of Goiás during fructification period (September and October), while Araticum (March-April) and Jatobá (August-October) were purchased from local sellers in markets in Goiânia city. Fruits were transported to the laboratory and promptly washed with plenty current water. Peels and pulps were removed with a clean knife and extracted seeds were stored in clean plastic bags at $-18{ }^{\circ} \mathrm{C}$ until their use in the experiments.

\subsection{Toxicity tests}

Seed heating was carried out using an electric laboratory oven with a thermostat for temperature control (FANEM Mod.315-SE, SP-Brazil). For each treatment, approximately $10 \mathrm{~g}$ of seeds were placed into the oven, lying on open aluminum trays. After treatment at selected temperatures and heating times, seeds were broken with a hammer and $5.0 \mathrm{~g}$ of the inner kernels were blended in $10 \mathrm{~mL}$ of distilled water. Raw extract was filtered through $0.45 \mu \mathrm{m}$ Millipore membrane and then used for bioassay tests. Positive controls for toxic seed extracts were prepared using the same amounts of non treated fresh kernels.

For toxicity evaluation, Artemia salina bioassay was choosen for being a simple, fast and cheap, but also sensitive and reliable method. Moreover, since previous toxicity evaluation in these seeds was performed using this assay, it would be recommendable to use the same biological model to assess toxicity decrease after thermal treatment. Cultures were prepared following the method previously developed for cyanide assay in seeds from commercial fruits (Garcia-Rodriguez et al., 2009) and other biological samples (Garcia-Rodriguez et al., 2004). $0.2 \mathrm{~g}$ of Artemia salina eggs were put into $200 \mathrm{~mL}$ of $35 \mathrm{~g}$ per liter (3.5\%) marine salt solution, under constant aeration and illumination, until eclosion after 48 hours. Newborn nauplia were caught with a Pasteur pipette and placed into glass test tubes (10 individuals in $1 \mathrm{~mL}$ of marine salt solution at the same concentration as used for eclosion ( $35 \mathrm{~g}$ per liter).

$100 \mu \mathrm{L}$ of each extract were added to triplicate test tubes and after a 24 hour incubation period living and dead or immobilized nauplia were counted to calculate percentage survival. This extract volume was chosen from previous results as the minimum quantity of concentrated seed extract needed to induce death of all Artemia salina individuals in test tubes ( $0 \%$ survival). A survival value figure of $90 \%$ or higher was chosen as acceptable toxin inactivation criteria after thermal treatment.

\subsection{Statistical analysis}

The results were expressed as a mean \pm standard deviation. The variance analysis and Tukey's test were used to define differences in mean values from three replicates. Results from CCRD were analyzed using Statistica 6.0 software (Statsoft, Inc., Tulsa, USA, 1997).

\section{Results and discussion}

The inhibitory effect of temperature and heating time on toxicity was observed in Cagaita, Mangaba and Jatobá seeds where Artemia salina survival increased after treatment with heated seed extracts, but not in Araticum, where values remained at $0 \%$ even after treatment with extracts of seeds exposed at the highest temperatures and for the longest heating times tested.

Factors investigated in the CCRD, as well as the coded and decoded levels, and the Artemia survival results for the toxicity inactivation tests are shown in Table 1 (for Cagaita and Mangaba) and in Table 2 (for Jatobá).

The results of multivariate analysis showed that all factors, except the quadratic term of temperature significantly affected $(\mathrm{p} \leq 0.10)$ the toxicity of Cagaita seeds (Table 3$)$. As can be observed, both time factor and linear term of temperature positively affected response, however, the interaction factor

Table 1. Factors coded (in parenthesis) and decoded levels used in the central composite rotatable design and the mean response obtained from toxicity inactivation tests for Cagaita and Mangaba seeds.

\begin{tabular}{|c|c|c|c|c|}
\hline \multirow[b]{2}{*}{ Run } & \multicolumn{2}{|c|}{ Actual and coded levels of variables } & \multicolumn{2}{|c|}{ Artemia survival (\%) } \\
\hline & $\begin{array}{c}\text { Temperature }\left({ }^{\circ} \mathrm{C}\right) \\
\mathrm{X} 1\end{array}$ & $\begin{array}{l}\text { Heating time (min) } \\
\text { X2 }\end{array}$ & Cagaita & Mangaba \\
\hline 1 & 78 & 0.5 & $10+0$ & $87+6$ \\
\hline 2 & 78 & 2 & $33+6$ & $10+0$ \\
\hline 3 & 78 & 10 & $100+0$ & $93+6$ \\
\hline 4 & 98 & 0.5 & $57+6$ & $93+6$ \\
\hline 5 & 98 & 2 & $50+8$ & $97+6$ \\
\hline 6 & 98 & 10 & $63+6$ & $90+8$ \\
\hline 7 & 110 & 0.5 & $53+6$ & $73+6$ \\
\hline 8 & 110 & 2 & $77+6$ & $83+6$ \\
\hline $9(\mathrm{C})$ & 110 & 10 & $93+6$ & $100+0$ \\
\hline $10(\mathrm{C})$ & 110 & 10 & $93+6$ & $100+0$ \\
\hline
\end{tabular}


Table 2. Factors coded (in parenthesis) and decoded levels used in the central composite rotatable design and the mean response obtained from toxicity inactivation tests for Jatobá seeds.

\begin{tabular}{|c|c|c|c|}
\hline \multirow[b]{2}{*}{ Run } & \multicolumn{2}{|c|}{ Actual and coded levels of variables } & \multirow{2}{*}{$\begin{array}{c}\text { Artemia survival (\%) } \\
\text { Jatobá }\end{array}$} \\
\hline & $\begin{array}{c}\text { Temperature }\left({ }^{\circ} \mathrm{C}\right) \\
\mathrm{X} 1 \\
\end{array}$ & $\begin{array}{l}\text { Heating time (min) } \\
\text { X2 }\end{array}$ & \\
\hline 1 & 105 & 6 & $0+0$ \\
\hline 3 & 160 & 6 & $100+0$ \\
\hline 4 & 105 & 9 & $\mathbf{0}+\mathbf{0}$ \\
\hline 7 & 105 & 12 & $\mathbf{0}+\mathbf{0}$ \\
\hline 8 & 130 & 12 & $97+6$ \\
\hline $9(\mathrm{C})$ & 160 & 12 & $100+0$ \\
\hline $10(\mathrm{C})$ & 160 & 12 & $100+0$ \\
\hline
\end{tabular}

Table 3. Effects and correlation coefficients among factors obtained from the central composite rotatable design for toxicity inactivation of seeds.

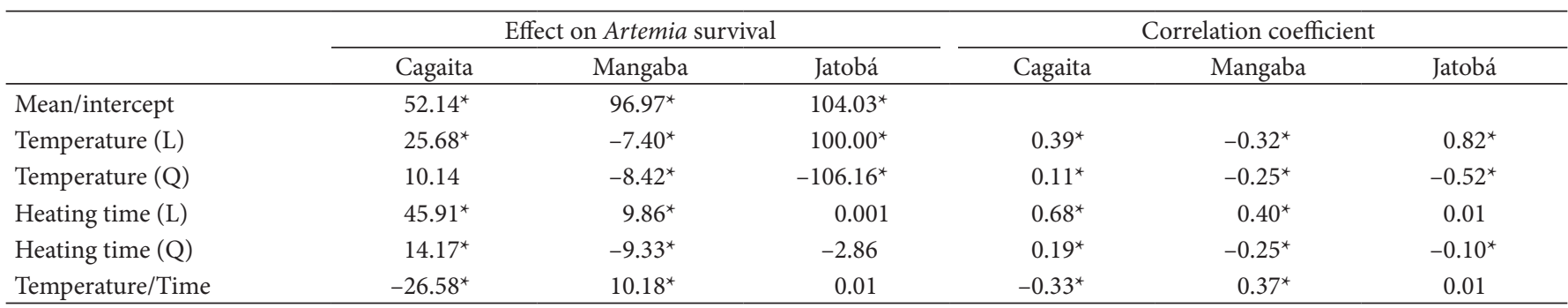

*Variables presenting values statistically significant $(\mathrm{p}=0.001)$.

(time/temperature) had a negative effect on Artemia survival. In addition, the correlation analysis showed that linear terms of heating time and temperature had the most pronounced effect on toxicity inactivation (Table 3 ).

The highest percentage of Artemia survival was observed when Cagaita seeds were heated for $10 \mathrm{~min}$. The desirability function method was used to obtain optimal conditions for toxicity inactivation of Cagaita seeds. The results showed that desirability increased as a function of heating time (Figure 1a). After numerical optimization based on the highest desirability, the maximum percentage of Artemia survival could be obtained by heating Cagaita seeds at $95^{\circ} \mathrm{C}$ for $10 \mathrm{~min}(\mathrm{~d}=0.85)$, even though a survival rate higher than $90 \%$ can be observed after $10 \mathrm{~min}$ heating at $78^{\circ} \mathrm{C}$.

The percentage of Artemia survival after treatment with an aqueous extract of Mangaba seeds is shown in Table 1. Multivariate analysis showed that both heating time and temperature factors affected the toxicity inactivation of seeds (Table 3). As can be seen, the linear term of heating time and the interaction factor had a positive effect on Artemia survival. However, the linear and quadratic terms of temperature and the quadratic term of heating time negatively affected the response. A complete toxin inactivation was obtained when Mangaba seeds were heated at $78{ }^{\circ} \mathrm{C}$ or $98{ }^{\circ} \mathrm{C}$ for $2 \mathrm{~min}$. In addition, considering that an efficient toxin inactivation should provide at least $90 \%$ Artemia survival, the toxic compounds present in Mangaba seeds were more thermo-labile that those present in Cagaita seeds (Table 1).
The desirability surface as a function of temperature and heating time for toxin inactivation of Mangaba seeds is presented in Figure 1b. As can be observed, as heating time increases, so does desirability. Results for numerical optimization via the desirability method showed that better values for Artemia survival can be obtained by incubating Mangaba seeds at $97.5^{\circ} \mathrm{C}$ for $7.8 \mathrm{~min}(\mathrm{r}=0.94)$.

Table 2 shows the results of thermal inactivation tests from Jatobá seeds and the factors investigated in the CCRD, as well as the coded and decoded levels, and Artemia survival results for the parameters tested. As can be observed in Table 2, toxic compounds from Jatobá seeds presented higher thermal stability than those from Cagaita and Mangaba, since exposure of the seeds to $105^{\circ} \mathrm{C}$ did not show any toxin inactivation even after 12 minutes of heating. The highest percentage of Artemia survival was observed by heating Jatobá seeds at $130^{\circ} \mathrm{C}$ for 9 min or at $160{ }^{\circ} \mathrm{C}$ for at least $6 \mathrm{~min}$.

The effect of the factors studied on Artemia survival after treatment with Jatobá seed extracts are also shown in Table 3, in addition to those caused by interactions among the factors. The multivariate analysis results indicated that the linear term of temperature positively affected Artemia survival $(\mathrm{p}<0.05)$ while the quadratic term of temperature had a negative effect on the response. In addition, the quadratic term of heating time had a slight negative correlation with Artemia survival while the linear term of heating time and the interaction of factors had no effect or correlation with the inactivation of toxic compounds from Jatoba seeds. 
2 factors, 1 Blocks, 30 Runs; MS Residual=264,7932 DV: Cagaita

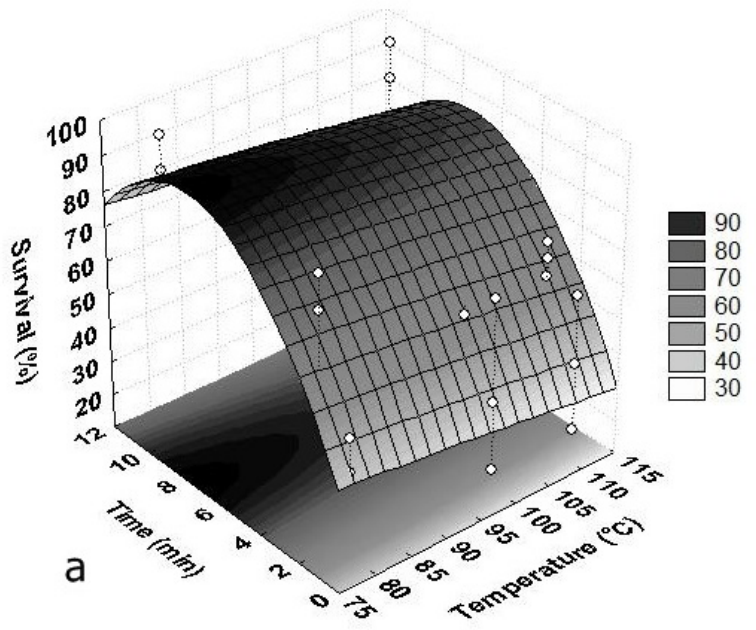

2 factors, 1 Blocks, 30 Runs; MS Residual=137,5288 DV: Mangaba

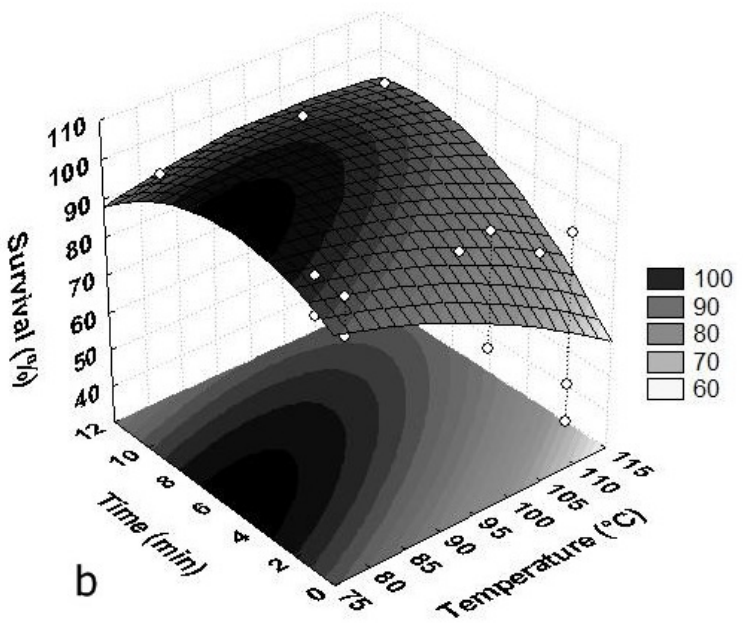

Jatoba $=$ Distance Weighted Least Squares

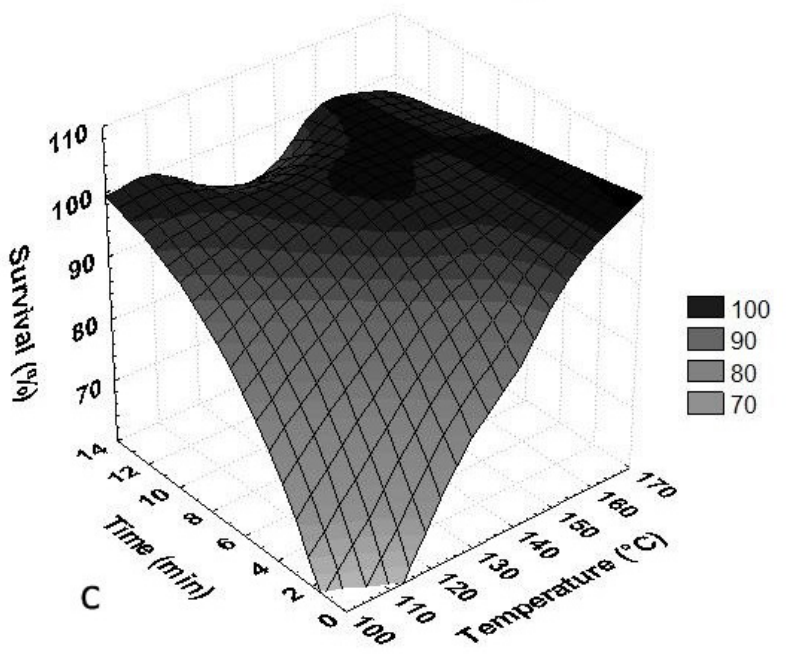

Figure 1. Response surfaces showing the effect of temperature and heating time on seed toxicity from Cagaita (a); Mangaba (b) and Jatobá (c) seeds, tested on Artemia salina cultures.
The desirability surface results for toxin inactivation of Jatobá seeds showed that desirability increased as a function of temperature (Figure 1c). Therefore, the optimal condition for toxin inactivation was determined by a numerical method based on desirability function, by which the optimal conditions for a maximum percentage of Artemia survival were found at $131.5^{\circ} \mathrm{C}$ for $9 \min (\mathrm{d}=0.99)$.

The temperature inhibitory effect on extract toxicity showed a clearly different behavior in each of the seed extracts tested. This effect reflects the different thermal stability of each toxic compound from Cagaita, Mangaba, Jatobá and Araticum seeds.

The most labile toxins are those from Mangaba, followed by Cagaita seeds. This observation could suggest the presence of thermo-labile water-soluble toxins with a protein structure or those formed after some enzymatic reaction, such as hydrocyanic acid. Nevertheless, previous experiments using the cyanide specific Guignard test showed negative results in all seed extracts (Fonseca et al., 2013), discarding the possibility of cyanide being the compound responsible for their toxicity. The structure of the toxic compounds in the seeds of Cagaita and Mangaba was not completely elucidated yet, although previous studies showed the presence of tannins and other phenolic compounds in Cagaita seeds (Rocha et al., 2011; Roesler et al., 2007). Such compounds can have cytotoxic and antibacterial activity, which could also explain their toxicity. It was suggested the presence of enzymes such as peroxidase and poliphenol-oxidase in the Mangaba seeds (Moura et al., 2015). Those enzymes can express a low toxicity and could be easily degraded by moderate high temperatures and even by some bacteria and fungi.

The toxic compounds from Jatobá seeds presented a higher thermal stability than those from Cagaita and Mangaba, a temperature of $110^{\circ} \mathrm{C}$ being necessary for 6 minutes to observe a survival of $96.67 \%$ (Table 2), while seed exposure at $105^{\circ} \mathrm{C}$ did not show any inhibitory effect even after 12 minutes heating.

The presence of proteases and trypsin inhibitors has been reported in several leguminous seed families, to which Jatobá belongs. Assessing these compounds in the seeds of several fruits from the Brazilian central plain, Caramori and collaborators found higher concentrations of these inhibitors in Jatobá, while seeds of Araticum presented the lowest values (Caramori et al., 2004). Other authors have described two groups of tripsin inhibitors with significantly different thermal stability in leguminous seeds such as kidney beans and soya beans (Carvalho et al., 2002; Khattab et al., 2009; Lajolo \& Genovese, 2002; Shimelis \& Rakshit, 2007). One of these fractions can be totally inhibited after 10 minutes heating at $70^{\circ} \mathrm{C}$ (Calderon et al., 2010) while the other shows an activity reduction of $50 \%$ at $95^{\circ} \mathrm{C}$ (Miura et al., 2005) or $70 \%$ at $100^{\circ} \mathrm{C}$ (Kadam et al., 1986), both after 1 hour of heating. This fact together with the existence of high concentrations of antitrypsins, could explain the inactivation effect observed in Jatobás toxicity at a higher temperature over a shorter time, suggesting the presence of the more stabile fraction of trypsin inhibitors.

Toxins from Araticum seeds were the most resistant, showing $0 \%$ survival values even after heating at $160^{\circ} \mathrm{C}$ for 12 minutes, which generated a flat-shaped response surface out of zero value points (not shown), precluding further statistical processing. 
Several authors (Kim et al., 2001; Pardhasaradhi et al., 2005; Colom et al., 2006) have described the presence of tetrahydrofuran - acetogenin related toxins in the seeds of some annonaceous fruits that belong to the same taxonomic genus as Araticum. These toxins are known as potent inhibitors of mitochondrial respiration that have a similar action mechanism to cyanide. To confirm whether the observed thermal stability of toxins from Araticum is common to annonaceous fruits, seeds of the commercial fruits Ata (Annona squamosa) and Atemóia (a hybrid resulting from crossing Annona cherimola and Annona squamosa) were also exposed to a temperature of $160^{\circ} \mathrm{C}$ for 12 minutes. After treatment, extracts from Ata and Atemóia seeds proved to be equally toxic to Artemia salina cultures, with survival values of $0 \%$. This similar behavior suggests the presence of the same toxins, likely acetogenins, in the seeds of annonaceous fruits, and even Araticum. Experiments were not conducted at temperatures higher than $160^{\circ} \mathrm{C}$ as such may cause significant alterations of color and smell due to Maillard reactions forming furfural derivatives that could also be toxic for Artemia salina cultures, thus interfering with inactivation studies.

Identification of toxic compounds is still in progress, but not finished yet. The present work can be considered as a part of those studies, which also include biochemical assays and action mechanism on living cell cultures and living tissues. Further experiments shall be carried out to identify and characterize toxic components in all seeds and kernels shown to be toxic by Artemia salina bioassay. This work was focused on thermal resistance or sensitivity of toxic compounds as a useful knowledge not only for scientific community, but also for fruit derivatives producers, in order to improve food safety during manufacturing procedures. The results confirm the need to adopt safety procedures during the manufacture of industrialized derivatives of these fruits, in order to minimize toxicity risks after their consumption. If possible, seed breaking should be avoided during automatic pulp removal. Moreover, a common pasteurization procedure before industrial processing could be an effective method to inactivate toxic compounds in Cagaita and Mangaba seeds, though it would not be effective on Jatobá and Araticum toxins.

\section{Conclusions}

1-The most labile toxins were found in Mangaba seeds which were inactivated after exposure to $78^{\circ} \mathrm{C}$ for 2 minutes, followed by toxins from Cagaita seeds which were inactivated after 10 minutes exposure at $78^{\circ} \mathrm{C}$.

2-Statistical analysis showed a significant effect for both temperature and heating time factors for inactivation of toxins from Cagaita and Mangaba seeds, while the temperature factor presented the main effect on toxicity reduction for Jatobá seeds.

3-Toxic compounds from Jatobá seeds were more stable than those from Cagaita and Mangaba seeds, which is probably a thermo-resistant fraction of protease inhibitors. Araticum toxins were the most stable, remaining active after 12 minutes at $160^{\circ} \mathrm{C}$, just like toxins from other annonaceous fruits which suggests the presence of acetogenins.
4-The results presented here could be useful for the inclusion of preventive and safety procedures in manufacturing protocols for industrial products derived from such fruits.

\section{Acknowledgements}

Fundação de Amparo à Pesquisa do Estado de Goiás (FAPEG); Prof. Dr. Ronaldo Veloso Naves, Escola de Agronomia, Universidade Federal de Goiás.

\section{References}

Araújo, J. M. A. (2004). Toxicantes naturais. In J. M. A. Araújo, Química de alimentos: teoria e prática (cap. 6; pp. 204-212). Viçosa: Editora da UFV.

Calderon, L. A., Almeida, H. A. Fo., Teles, R. C. L., Medrano, F. J., Bloch, C. Jr., Santoro, M. M., \& Freitas, S. M. (2010). Purification and structural stability of a trypsin inhibitor from Amazon. Ingacylindrica [Vell] Mat. seeds. Brazilian Journal of Plant Physiology, 22(2). Retrieved from http://www.scielo.br/scielo. php?pid=S167704202010000200001\&script=sci_arttext \#nota 1

Caramori, S. S., Lima, C. S., \& Fernandes, K. F. (2004). Biochemical characterization of selected plant species from Brazilian savannas. Brazilian Archives of Biology and Technology, 47(2), 253-259. http:// dx.doi.org/10.1590/S1516-89132004000200013.

Carvalho, M. R. B., Kirschnik, P. G., Paiva, K. C., \& Aiura, F. S. (2002). Avaliação da atividade dos inibidores de tripsina após digestão enzimática em grãos de soja tratados termicamente. Revista de Nutrição, 15, 267-272.

Colom, O. A., Neske, A., Popich, S., \& Bardon, A. (2006). Toxic effects of annonaceous acetogenins from Annona cherimolia (Magnoliales: Annonaceae) on Spodoptera frugiperda (Lepidoptera: Noctuidae). Journal of Pest Science, 80(1), 63-67. http://dx.doi.org/10.1007/ s10340-006-0149-2.

Fernandez, M. T., \& Novelli, A. (1997). Toxinas naturales contenidas o contaminantes de los granos y tubérculos. In M. T. Fernandez \& A. Novelli, Bioquímica de los alimentos. (cap. 7; pp. 79-84). Oviedo.

Fonseca, R. C., Souza, N. A., Correa, T. C. L., Garcia, L. F., Reis, L. G. V., \& Garcia-Rodriguez, A. (2013). Assessment of toxic potential of Cerrado fruit seeds using Artemia salina bioassay. Food Science and Technology (Campinas.), 33(2), 251-256. http://dx.doi.org/10.1590/ S0101-20612013005000032.

Garcia-Rodriguez, A., Caetano, G. G. I., Borges, M. B., Santos, C. A., \& Cardoso, G. S. (2004). Toxicidade por Microcystis em Goiás: Estudo dos efeitos tóxicos em camundongos e Artemias salinas. Estudos, 31(9), 1595-1606.

Garcia-Rodriguez, A., Teixeira, O. M., Salles, F. G., Vital, J. P., \& Silva, D. P. (2009). Bioensaio com Artemia salina para detecção de toxinas em alimentos vegetais. Estudos, 36(4), 795-808.

Kadam, S. S., Ghorpade, V. M., Adsule, R. N., \& Salunkhe, D. K. (1986). Trypsin inhibitor in moth bean: thermal stability and changes during germination and cooking. Quality in Plant Food Human Nutrition, 36(1), 43-46. http://dx.doi.org/10.1007/BF01091752.

Khattab, R. Y., Arntfield, S. D., \& Nyachoty, C. M. (2009). Nutritional quality of legume seeds as affected by some physical treatments. Part 1: protein quality evaluation. LWT - Food Science and Technology (Campinas.), 42, 1107-1112.

Kim, D. H., Son, J. K., \& Woo, M. H. (2001). Annomocherin, Annonacin and Annomontacin: a novel and two known Bioactive monotetrahydrofuran annonaceous acetogenins from Annona cherimolia 
seeds. Archives of Pharmacal Research, 24(4), 300-306. http://dx.doi. org/10.1007/BF02975096. PMid:11534761.

Lajolo, F. M., \& Genovese, M. I. (2002). Nutritional significance of lectins and enzyme inhibitors from legumes. Journal of Agricultural and Food Chemistry, 50(22), 6592-6598. http://dx.doi.org/10.1021/ jf020191k. PMid:12381157.

Midio, A. F., \& Martins, D. I. (2000). Agentes tóxicos naturalmente presentes em alimentos. In A. F. Midio \& D. I. Martins, Toxicologia de alimentos (cap. 2; pp. 31-47). São Paulo: Livraria Varela.

Miura, E. M. Y., Silva, R. S. S. F., Mizubuti, I. Y., \& Ida, E. I. (2005). Cinética de inativação de inibidores de tripsina e insolubilização de proteínas de diferentes cultivares de soja. Revista Brasileira de Zootecnia, 34(5), 1659-1665. http://dx.doi.org/10.1590/S151635982005000500028.

Moura, L. C., Oliveira, K. B., Vitorino, L. C., Megger, C., Silva, M. A. P., \& Silva, N. F. (2015). Atividade de enzimas oxidativas em frutos de mangaba. In Proceedings of the III INORVAGRI International Meeting, Fortaleza, Brasil.

Pardhasaradhi, B. V. V., Reddy, M., Ali, A. M., Kumari, A. L., \& Khar, A. (2005). Differential cytotoxic effects of Annona squamosa seed extracts on human tumour cell lines: role of reactive oxygen species and glutathione. Journal of Biosciences, 30(2), 237-244. http://dx.doi. org/10.1007/BF02703704. PMid:15886460.

Rocha, C., Cobucci, R. M. A., Maitan, V. R., \& Silva, O. C. (2008). Elaboração e avaliação de iogurte sabor frutos do Cerrado. Boletim do Centro de Pesquisa e Processamento de Alimentos, 26, 255-266.
Rocha, W. S., Lopes, R. M., Silva, D. B., Vieira, R. F., Silva, J. P., \& Agostini-Costa, T. S. (2011). Compostos fenólicos totais e taninos condensados em frutas nativas do Cerrado. Revista Brasileira de Fruticultura, 33(4), 1215-1221. http://dx.doi.org/10.1590/S010029452011000400021.

Roesler, R., Malta, L. G., Carrasco, L. C., Holanda, R. B., Sousa, C. A. S., \& Pastore, G. M. (2007). Atividade antioxidante de frutas do Cerrado. Ciência e Tecnologia de Alimentos, 27(1), 53-60. http:// dx.doi.org/10.1590/S0101-20612007000100010.

Shimelis, E. A., \& Rakshit, S. K. (2007). Effect of processing on antinutrients and in vitro protein digestibility of kidney bean (Phaseolus vulgaris L.) varieties grown in East Africa. Food Chemistry, 103(1), 161-172. http://dx.doi.org/10.1016/j.foodchem.2006.08.005.

Silva, A. M. L., Gomes, A. C. G., \& Martins, B. A. (2009). Alterações físico-químicas e estudo enzimático da polpa de araticum (Annona crassiflora Mart.). Estudos, 36, 775-783.

Silva, A. M. L., Sa, E. C., Gonçalves, M. L., Assis, R. S., Silva, R. G., \& Leles, M. I. G. (2004). Análises físico-químicas e avaliação da composição centesimal de frutas do cerrado. Estudos, 31(9), 1635-1642.

Silva, L. M. (2011). Efeito modulador da polpa de graviola (Annona muricata) sobre a carcinogenicidade da mitomicina $\mathrm{C}$, avaliado por meio do teste para detecção de clones de tumor (warts) em Drosophila melanogaster. Perquirere - Revista do Núcleo Interdisciplinar de Pesquisa e Extensão, 1(8), 80-94. 